\title{
Heterochromatin variation in chromosomes of Anopheles (Nyssorhynchus) darlingi Root and A.(N.) nuneztovari Gabaldón (Diptera: Culicidae)
}

\author{
Míriam Silva Rafael and Wanderli Pedro Tadei
}

\begin{abstract}
C-banding was used to study the variations in heterochromatic block markings in chromosomes of Anopheles darlingi and A. nuneztovari from Manaus, State of Amazonas, and Macapá, State of Amapá, Brazil. Both species had two differently shaped X chromosomes and a $\mathrm{Y}$ chromosome that was entirely heterochromatic. The $\mathrm{X}_{1}$ chromosome of $A$. darlingi had markings that extended $1 / 3$ of the total length whereas in the $\mathrm{X}_{2}$ chromosome the markings were located around the centromeric region. The markings on autosomal chromosomes were concentrated in the centromeric region in both species, with a heterochromatic block in one arm of chromosome II of $A$. darlingi. A. nuneztovari had three heterochromatic blocks in chromosome $\mathrm{X}_{1}$ (longer) and two blocks in $\mathrm{X}_{2}$ (shorter). $\mathrm{X}_{2} \mathrm{X}_{2}$ females were not detected in either species. The $\mathrm{X}_{1}$ and $\mathrm{X}_{2}$ chromosomes of males were found in A. darlingi, whereas in A. nuneztovari only the $\mathrm{X}_{1}$ chromosome was detected. Only intraspecific variation was found in heterochromatic block markings in the sex chromosomes and autosomes in the two populations of both species at each location.
\end{abstract}

\section{INTRODUCTION}

Anopheles (Nyssorhynchus) darlingi Root, 1926, is the main vector of human malaria in the Amazon region. Anopheles (N.) nuneztovari Gabaldón, 1940, is an important vector in Venezuela and Colombia, but its vectorial capacity in Brazil is controversial (Deane et al., 1948; Deane, 1986; Tadei et al., 1993, 1998).

Chromosomal studies of $A$. darlingi populations from Minas Gerais, Brazil, and of other South American species showed a karyotype of $2 n=6$ (Schreiber and Guedes, 1959), as in other Anopheles species (Coluzzi, 1988). Rafael and Tadei (1998) reported an identical karyotype $(2 \mathrm{n}=6)$ for $A$. darlingi and A. nuneztovari populations from the Amazon region.

C-banding analysis of mitotic chromosomes of Anopheles species from continental Asia (Baimai et al., 1995) revealed species complexes which included Anopheles dirus (Baimai, 1984; Hii, 1985) and Anopheles maculatus in the Neocellia series (Cellia) (Baimai et al., 1993). C-banding was reported to be useful for identifying sibling species based on differences in the morphology, quantity and distribution of heterochromatic blocks, principally in $\mathrm{X}$ and $\mathrm{Y}$ chromosomes (Baimai et al., 1993).

In spite of the epidemiological importance of $A$. darlingi and A. nuneztovari in the Amazon region, there are no data on C-banding of the metaphase chromosomes of these species. We studied the variation in heterochromatic block markings in metaphase chromosomes to determine the heterochromatic patterns in the Manaus and Macapá populations of these species.

\section{MATERIAL AND METHODS}

Two natural populations of $A$. darling $i$ were sampled, with 20 individuals from Manaus $\left(3^{\circ} 08^{\prime} \mathrm{S}, 60^{\circ} 01^{\prime} \mathrm{W}\right)$, Amazonas State, and 14 from Macapá $\left(0^{\circ} 02^{\prime} \mathrm{S}, 51^{\circ} 03^{\prime} \mathrm{W}\right)$, Amapá State. For A. nuneztovari, 17 individuals from Manaus and 11 from Macapá were analyzed. Slides were prepared from fourth instar larval brain ganglia, treated with a $0.005 \%$ colchicine-hypotonic solution, as described by Imai et al. (1988). The slides were washed with distilled water, air dried and stored at room temperature for $72 \mathrm{~h}$. C-banding was done using the method of Sumner (1972), with a reduction in the barium exposure time (3 min). The best preparations were photographed using a phase-contrast microscope fitted with a green filter.

\section{RESULTS}

The C-banding patterns of 76 out of $103 \mathrm{~A}$. darling $i$ metaphases from Manaus and 57 out of 74 from Macapá, as well as 63 A. nuneztovari metaphases out of 86 from Manaus and 46 out of 53 from Macapá were photographed and analyzed. A. darling $i$ and $A$. nuneztovari populations from both localities showed two types of $\mathrm{X}$ chromosomes $\left(\mathrm{X}_{1}\right.$ and $\left.\mathrm{X}_{2}\right)$, which differed in the content and distribution of heterochromatic blocks (Figure 1). In A. darlingi from Manaus, the sex chromosomes had centromeric markings that extended to $1 / 3$ of $\mathrm{X}_{1}$ while the $\mathrm{Y}$ chromosome was entirely heterochromatic (Figure 2). The $\mathrm{X}_{2}$ chromosomes of samples from Macapá (Figure 2B) showed fewer markings, which extended only to the centromeric region. These marking patterns were the same as that of $A$. darlingi from 

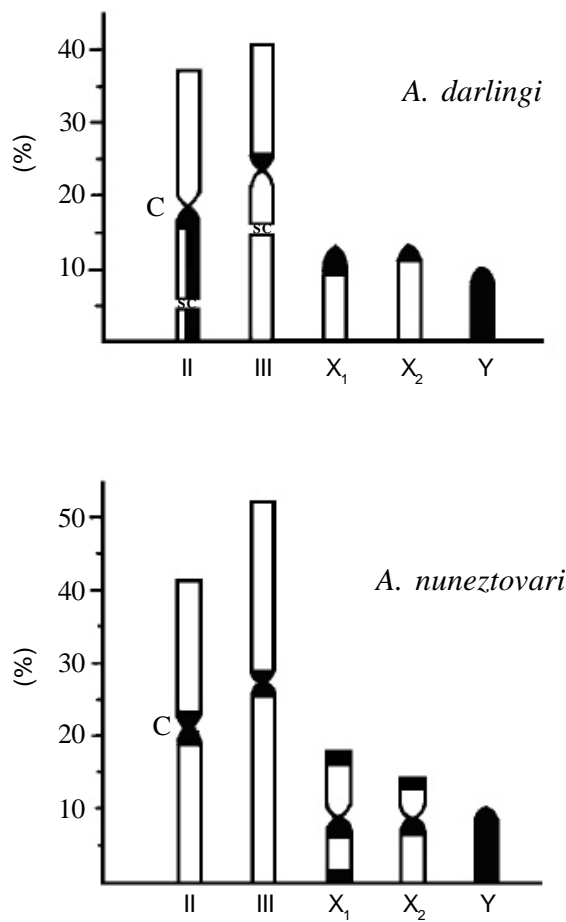

Figure 1 - Diagrammatic comparison of metaphase karyotypes of Anopheles darlingi and Anopheles nuneztovari from Manaus and Macapá. Only one set of autosomes (II and III) is shown. Variable heterochromatic portions are indicated in black. Chromosomes and heterochromatic portions are shown as a percentage of the total length. $\mathrm{c}=$ Centromeric region; $\mathrm{sc}=$ secondary constriction.

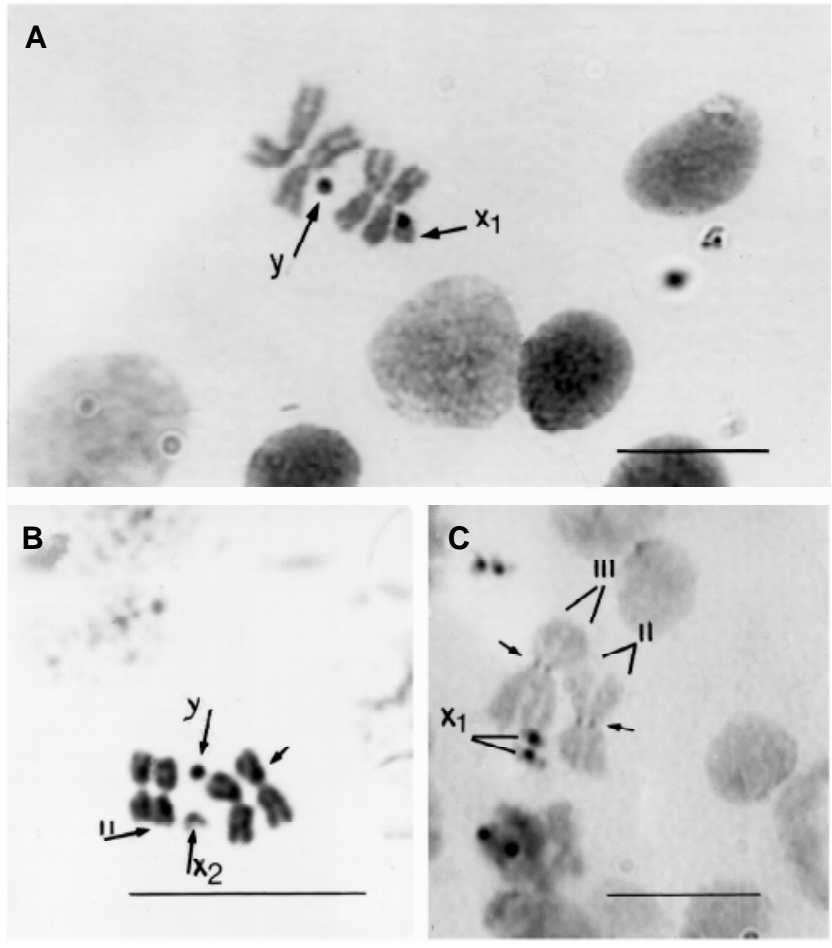

Figure 2 - Metaphase karyotypes from larval neuroblast cells of Anopheles darlingi. $\mathrm{A}=$ Male from Manaus; $\mathrm{B}=$ male from Macapá; $\mathrm{C}=$ female from Manaus. Long arrows $=\mathrm{X}_{1} \mathrm{X}_{2}$ chromosomes. Short arrows $=$ centromeric markings. $\mathrm{Bar}=10 \mu \mathrm{m}$.
Manaus. Chromosomes with a longer barium exposure (4 min) were more discolored than other preparations, although centromeric markings were seen in autosomes II and III and in the $\mathrm{X}_{1} \mathrm{X}_{1}$ sex pairs (Figure $2 \mathrm{C}$ ).

The C-banding pattern in autosomes of the $A$. darlingi population from Macapá was the same as that of $A$. darlingi from Manaus (Figure 1). In these populations, the II and III chromosomes had well-marked centromeric regions (Figure 2B and C). All of the II chromosomes had a band which extended from the centromere along half the length of one arm of the chromatid in each population (Figure 2B).

The variations in heterochromatic block markings in $\mathrm{X}_{1}, \mathrm{X}_{2}$ and autosomal chromosomes of the $A$. nuneztovari from Manaus were the same as that of $A$. nuneztovari from Macapá (Figure 1). The $X_{1}$ chromosome (longer) consisted of three heterochromatic blocks (two telomeric and one centromeric) and the $\mathrm{X}_{2}$ chromosome (shorter) contained two heterochromatic blocks, one of which was telomeric and the other centromeric (Figure 3A, B and C). The $\mathrm{X}_{2}$ chromosomes of female A. nuneztovari had two heterochromatic blocks (Figure 3 ). The centromeric heterochromatin markings of the autosomes were found in this species (Figure 3D and E).

$\mathrm{X}_{2} \mathrm{X}_{2}$ A. darlingi and A. nuneztovari females were not found (Table I). $\mathrm{X}_{1}$ and $\mathrm{X}_{2}$ males were found in $A$. darlingi while $A$. nuneztovari males had only the $\mathrm{X}_{1}$ chromosome.

\section{DISCUSSION}

C-banding studies of mitotic and meiotic chromosomes have provided important information on inter- and intraspecific population variation in Anopheles species and the technique has proven to be an excellent tool for identifying species complexes (Baimai et al., 1993). In this study the analysis of mitotic chromosomes of $A$. darlingi and $A$. nuneztovari described above revealed intraspecific variation in the quantity and distribution of heterochromatic blocks in sex chromosomes and in the centromeric regions of autosomes (Figure 1). Kitzmiller (1977) and Tadei (1985) suggested that in Anopheles genus the $\mathrm{X}$ chromosome was more sensitive to rearrangements than the autosomes. Intraspecific variation in sex chromosomes through the acquisition of constitutive heterochromatin is a common phenomenon in Southeast Asian anophelines. Baimai et al. (1996) reported two types of $\mathrm{X}$ chromosomes with floating frequencies in natural populations of Anopheles willmori. The X chromosomes in Amazonian populations of $A$. darlingi and A. nuneztovari most likely have similar mechanisms of adaptation in order to survive in these populations.

The difference in size between the $\mathrm{X}_{1}$ and $\mathrm{X}_{2}$ chromosomes of A. nuneztovari may have resulted from the addition to or loss of part of one of these chromosomes. The addition or loss of chromosomal heterochromatin in 


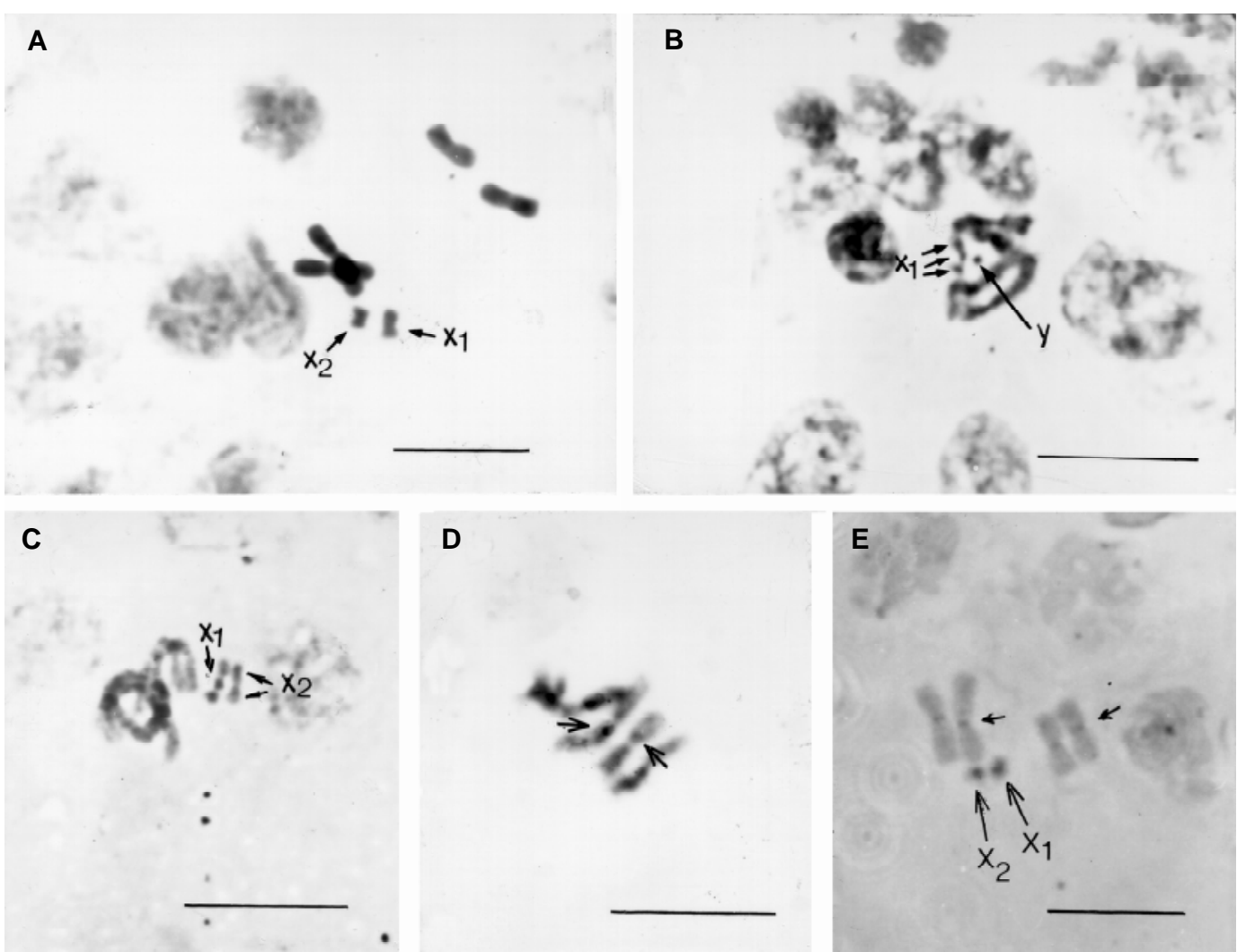

Figure 3 - Metaphase karyotypes from larval neuroblast cells of Anopheles nuneztovari. A = Female from Macapá; B = male from Manaus; , $\mathrm{D}=$ females from Manaus; $\mathrm{E}=$ female from Macapá. Short arrows $=$ centromeric markings. $\mathrm{Bar}=10 \mu \mathrm{m}$.

Table I - $\mathrm{X}_{1}$ and $\mathrm{X}_{2}$ chromosomes in females and males of Anopheles darlingi and Anopheles nuneztovari populations from Manaus (MAO) and Macapá (MC).

\begin{tabular}{|c|c|c|c|c|c|c|c|}
\hline \multicolumn{2}{|c|}{$\begin{array}{l}\mathrm{N}^{\circ} \text {. of males and } \\
\text { females analyzed }\end{array}$} & \multicolumn{3}{|c|}{ Females } & \multicolumn{3}{|c|}{ Males } \\
\hline MAO & $\mathrm{MC}$ & $\begin{array}{l}\text { Chromosome } \\
\text { combination }\end{array}$ & MAO & $\mathrm{MC}$ & $\begin{array}{l}\text { Chromosome } \\
\text { combination }\end{array}$ & MAO & $\mathrm{MC}$ \\
\hline \multicolumn{8}{|c|}{ A. darlingi } \\
\hline \multirow[t]{3}{*}{20} & 14 & $\mathrm{X}_{1} \mathrm{X}_{2}$ & 7 & 5 & $X_{1} Y$ & 4 & 7 \\
\hline & & $\mathrm{X}_{1} \mathrm{X}_{1}$ & 2 & 1 & $\mathrm{X}_{2} \mathrm{Y}$ & 7 & 1 \\
\hline & & $\mathrm{X}_{2} \mathrm{X}_{2}$ & 0 & 0 & & & \\
\hline \multicolumn{8}{|c|}{ A. nuneztovari } \\
\hline \multirow[t]{3}{*}{17} & 11 & $X_{1} X_{2}$ & 6 & 3 & $X_{1} Y$ & 9 & 6 \\
\hline & & $\mathrm{X}_{1} \mathrm{X}_{1}$ & 2 & 2 & $\mathrm{X}_{2} \mathrm{Y}$ & 0 & 0 \\
\hline & & $\mathrm{X}_{2} \mathrm{X}_{2}$ & 0 & 0 & & & \\
\hline
\end{tabular}

Anopheles has played an important role in chromosomal evolution in Anopheles species (Vasantha et. al., 1982; Baimai et al., 1993, 1996). The $\mathrm{X}_{2}$ chromosome in Amazonian populations of $A$. nuneztovari could have been derived from the presumed $X_{1}$ through the loss of an extra heterochromatic block in the distal end of the chromosome arm.

The heterochromatic blocks of $A$. darlingi and $A$. nuneztovari are similar to those of Anopheles (Kerteszia) cruzii, according to Ramírez (1989) and Ramírez and Dessen $(1994,1996)$. The inversions in the latter species probably arose from differences in the homolog chromosomes of the same specimen. However, the inversion polymorphism detected in A. darlingi (Kreutzer et al., 1972; Tadei et al., 1982; Tadei, 1985) and A. nuneztovari (Kitzmiller et al., 1973; Conn et al., 1993) does not necessarily mean that inversions alone positioned the heterochromatic blocks in the chromosomes of these spe- 
cies. Rather, these blocks may have originated from differences accumulated during evolution, as proposed by Gatti et al. (1982) to account for differences in the heterochromatic patterns of Anopheles gambiae and Anopheles arabiensis.

The C-banding in the present study in A. darlingi and A. nuneztovari populations exhibited only intraspecific variation of the heterochromatic blocks in X chromosomes and autosomes. The $\mathrm{X}$ chromosomes presented greater variation in the content and distribution of heterochromatic blocks than did the autosomes.

\section{ACKNOWLEDGMENTS}

The authors thank Dr. Shirley M. Recco-Pimentel (UNICAMP, Campinas, SP) and Sílvia G. Pompolo (UF, Viçosa, MG) for their support. This work was funded by $\mathrm{CNPq}$, Instituto do Meio Ambiente (IBAMA) and PETROBRÁS.

\section{RESUMO}

Pela técnica do bandamento $\mathrm{C}$ detectou-se variação de marcação dos blocos heterocromáticos dos cromossomos de $A$. darlingi e A. nuneztovari de Manaus, Amazonas, e de Macapá, Amapá, Brasil. Os cromossomos sexuais de ambas as espécies mostraram duas formas de cromossomos $\mathrm{X}$ e o $\mathrm{Y}$ foi totalmente heterocromático. No cromossomo $\mathrm{X}_{1}$ de A. darlingi a marcação atingiu $1 / 3$ e no cromossomo $X_{2}$ foi apenas na região centromérica. Nos autossomos de ambas as espécies as marcações foram constantes nas regiões centroméricas, e o cromossomo II de $A$. darlingi mostrou um bloco heterocromático em um dos braços. A. nuneztovari mostrou polimorfismo de tamanho para o cromossomo $\mathrm{X}$, tendo o $\mathrm{X}$ maior $\left(\mathrm{X}_{1}\right)$ três blocos e o menor $\left(\mathrm{X}_{2}\right)$ dois blocos heterocromáticos. Fêmeas homozigotas $\left(\mathrm{X}_{2} \mathrm{X}_{2}\right)$ não foram detectadas nas duas localidades. Em machos de A. darlingi foram encontrados os cromossomos $\mathrm{X}_{1} \mathrm{e} \mathrm{X}_{2}$, enquanto que em machos de A. nuneztovari somente o cromossomo $\mathrm{X}_{1}$ foi detectado. Apenas variação intraespecífica de blocos heterocromáticos nos cromossomos $\mathrm{X}$ e nos autossomos foi registrada nas duas populações de ambas as espécies estudadas em cada localidade.

\section{REFERENCES}

Baimai, V. (1984). Review of the current situation regarding malaria vector species complexes and intraspecific variations in the following geographical area: South-East Asia. In: Malaria Vector Complexes and Intraspecific Variations: Relevance for Malaria Control and Orientation for Future Research (Orni, E. and Muir, D., eds.). UNDP/WORLD $B A N K / W H O$, Bangkok, pp. 35-47.

Baimai, V., Kijchalao, U., Rattanarithikul, R. and Green, C.A. (1993). Metaphase karyotypes of Anopheles of Thailand and Southeast Asia: II. Maculatus group, Neocellia series, subgenus Cellia. Mosq. Syst. 25: 116-123.

Baimai, V., Rattanarithikul, R. and Kijchalao, U. (1995). Metaphase karyotypes of Anopheles of Thailand and Southeast Asia: IV. The barbirostris and umbrosus species groups, subgenus Anopheles (Diptera: Culicidae). J. Am. Mosq. Control Assoc. 11: 323-328.

Baimai, V., Treesucon, A. and Kijchalao, U. (1996). Heterochromatin variation in chromosome $\mathrm{X}$ in a natural population of Anopheles willmori (Diptera: Culicidae) of Thailand. Genetica 97: 235-239.
Coluzzi, M. (1988). Anopheline mosquitoes: genetic methods for species differentiation. In: Malaria. Principles and Practice of Malariology (Wernsdorfer, W.H. and McGregor, S., eds.). Churchill Livingstone, Great Britain, pp. 411-430.

Conn, J., Puertas, Y.R. and Seawright, J.A. (1993). A new cytotype of Anopheles nuneztovari from western Venezuela and Colombia. J. Am. Mosq. Control Assoc. 9: 294-301.

Deane, L.M. (1986). Malaria vectors in Brazil. Mem. Inst. Oswaldo Cruz 81: 5-14.

Deane, L.M., Causey, O.R. and Deane, M.P. (1948). Notas sobre a distribuição e a biologia dos anofelinos das regiões nordestina e amazônica do Brasil. Rev. Serv. Espec. Saúde Pública. 1(4): 827-965.

Gatti, M., Bonaccorsi, S., Pimpinelli, S. and Coluzzi, M. (1982). Polymorphism of sex chromosome heterochromatin in the Anopheles gambiae complex. In: Recent Developments in the Genetics of Insect Disease Vectors (Steiner, W.W.M., Tabachnick, W.J., Rai, K.S. and Narang, S., eds.). Stipes Publ. Co., Champaign, Illinois, pp. 32-48.

Hii, J.L.K. (1985). Genetic investigations of laboratory stocks of the complex of Anopheles balabacensis Baisas (Diptera: Culicidae). Bull. Entomol. Res. 75: 185-197.

Imai, H.T., Taylor, R.W., Crosland, M.W.J. and Crozier, R.H. (1988). Modes of spontaneous chromosomal mutation and karyotype evolution in ants with reference to the minimum interaction hypothesis. Jpn. J. Genet. 63: 159-185.

Kitzmiller, J.B. (1977). Chromosomal differences among species of Anopheles mosquitoes. Mosq. Syst. 9: 112-122.

Kitzmiller, J.B., Kreutzer, R.D. and Tallaferro, E. (1973). Chromosomal differences in populations of Anopheles nuneztovari. Bull. W. H.O. 48: 435-445.

Kreutzer, R.D., Kitzmiller, J.B. and Ferreira, E. (1972). Inversion polymorphism in the salivary gland chromosomes of Anopheles darlingi Root. Mosq. News 32: 555-565.

Rafael, M.S. and Tadei, W.P. (1998). Metaphase karyotypes of Anopheles (Nyssorhynchus) darlingi Root and A. (N.) nuneztovari Gabaldón (Diptera; Culicidae). Genet. Mol. Biol. 21: 351-354.

Ramírez, C.C.L. (1989). Estudo cromossômico em uma população de Anopheles (Kerteszia) cruzii Dyar \& Knab, 1909. Master's thesis, Inst. de Biociências, USP, São Paulo.

Ramírez, C.C.L. and Dessen, E.M.B. (1994). Cytogenetic analysis of a natural population of Anopheles cruzii. Rev. Bras. Genet. 17: 41-46.

Ramírez, C.C.L. and Dessen, E.M.B. (1996). The polytene chromosomes of the mosquito Anopheles bellator compared with those of Anopheles cruzii. Braz. J. Genet. 19: 555-558.

Schreiber, G. and Guedes, A.S. (1959). Estudo comparativo do cromosoma $\mathrm{X}$ em algumas espécies de Anopheles do sub-gen. Nyssorhynchus (Dipt.: Culic.). Ciênc. Cult. 11: 128-129.

Sumner, A.T. (1972). A simple technique for demonstrating centromeric heterochromatin. Exp. Cell Res. 75: 304-306.

Tadei, W.P. (1985). Biology of Amazonian mosquitoes. IX. On chromosome polymorphism of Anopheles (Nyssorhynchus) darlingi and a new arrangement in the X-chromosome. Ciênc. Cult. 37: 1329-1331.

Tadei, W.P., Santos, J.M.M. and Rabbani, M.G. (1982). Biologia de anofelinos amazônicos. V. Polimorfismo cromossômico de Anopheles darlingi Root (Diptera, Culicidae). Acta Amazônica 12: 353-369.

Tadei, W.P., Santos, J.M.M., Scarpassa, V.M. and Rodrigues, I.B. (1993). Incidência, distribuição e aspectos ecológicos de espécies de Anopheles (Diptera: Culicidae), em regiões naturais e sob impacto ambiental da Amazônia brasileira. In: Bases Científicas para Estratégias de Preservação e Desenvolvimento da Amazônia (Ferreira, E.J.G., Santos, G.M., Leão, E.L.M. and Oliveira, L.A., eds.). INPA, Manaus, pp. 167-196.

Tadei, W.P., Dutary-Thatcher, B., Santos, J.M.M., Scarpassa, V.M., Rodrigues, I.B. and Rafael, M.S. (1998). Ecologic observations on anopheline vectors of malaria in the Brazilian Amazon. Am. J. Trop. Med. Hyg. 59: 325-335.

Vasantha, K., Subbarao, S.K., Adak, T. and Sharma, V.P. (1982). Karyotypic variations in Anopheles culifacies complex. Ind. J. Malariol. 19: $27-32$

(Received September 21, 1998 